\title{
CIÊNCIANATURA
}

\section{Identification of microbiological contamination and mutagenic potential of surface waters of the municipality of Dourados, MS}

\author{
Monyque Palagano da Rocha ${ }^{1}$, Jussara Oliveira Vaini ${ }^{2}$, Bruno do Amaral Crispim ${ }^{1}$, Leonardo de \\ Oliveira Seno ${ }^{3}$, Kelly Mari Pires de Oliveira ${ }^{4}$, Alexéia Barufatti Grisolia ${ }^{4}$ \\ ${ }^{I}$ Faculdade de Ciências Exatas e Tecnologia, Universidade Federal da Grande Dourados, Mato Grosso do Sul, Brasil \\ ${ }^{2}$ Universidade de Mogi das Cruzes, São Paulo, Brasil \\ ${ }_{-}^{3}$ Faculdade de Ciencias Agrárias, Universidade Federal da Grande Dourados, Mato Grosso do Sul, Brasil \\ ${ }^{4}$ Faculdade de Ciências Biológicas e Ambientais, Universidade Federal da Grande Dourados, Mato Grosso do Sul , Brasil
}

\section{Resumo}

O objetivo do estudo foi avaliar a qualidade da água do córrego Água Boa e lagos dos parques Arnulpho Fioravante e Antenor Martins (Dourados - MS), por meio de parâmetros fisico-químicos, análises microbiológicas e teste de mutagenicidade para monitorar a interferência proveniente de atividades antrópicas e a capacidade de depuração da água. Inicialmente as amostras de água foram processadas para análise de coliformes técnica do Número Mais Provável (NMP). Realizou-se o pré enriquecimento e enriquecimento das amostra e estriamento em Agar Desoxicolato Lisina Xilose (XLD) para pesquisa de Salmonella spp. Para avaliação da mutagenicidade foi realizado o esfregaço sanguíneo de espécimes de Astyanax lacustris coletados nos locais de estudo. O parque Arnulpho Fioravante apresentou as maiores médias para Condutividade Elétrica (353,5 uS cm $\left.{ }^{-2}\right)$, Sólidos Totais Dissolvidos (179,3 $\mathrm{mg} \mathrm{L}^{-1}$ ) e os maiores valores para coliformes totais. Salmonella spp também foram identificadas nas águas provenientes dos Lagos dos parques. Os maiores números de micronúcleo foram observados no córrego Água Boa. Considerando a contaminação microbiológica e o número elevado de micronúcleo, torna-se relevante ressaltar os efeitos das interferências antrópicas na biota local. Sendo de grande importância a intensificação da fiscalização de legislações municipais vigentes para que haja a conservação e preservação desses ecossistemas.

Palavras-chave: E.coli. Micronúcleo. Ambiente aquático.

Abstract

The aim of the study was to evaluate the water quality of the Agua Boa stream and the lakes of the parks Arnulpho Fioravante and Antenor Martins (Dourados - MS), through physico-chemical parameters, microbiological analysis and mutagenicity test to monitor interference from Antropic activities and water depuration capacity. Initially the water samples were processed for coliform analysis using the Most Probable Number (MPN) technique. For the research of Salmonella spp., it was performed the pre-enrichment and enrichment of the water sample and streaking in Xylose Lysine Deoxicolate (XLD) agar. For the evaluation of the mutagenicity, smear peripheral blood of the specimens Astyanax lacustris were collected from the places studied. The Arnulpho Fioravante Park had higher mean values for Electrical Conductivity (353.5 uS cm-2), Total Dissolved Solids (179.3 mg $\left.L^{-1}\right)$ and the highest values for total coliforms. Salmonella spp. it was identified in the water in both parks. The highest numbers of micronucleus were observed in Agua Boa stream. Considering microbiological contamination and higher micronucleus number, it's relevant to highlight the effects of anthropic interferences in local biota. Therefore, it's of great importance to intensify the supervision of the municipal legislation, in order to conserve and preserve these ecosystems. 


\section{1 introduccíon}

The population increase accompanied by agricultural and industrial growth threatens the balance of aquatic ecosystems, since water quality depends on natural conditions and land use and occupation in the watershed (SILVA et al., 2016). The flow of domestic sewage is the most significant contamination pathway when it comes to urban water resources (MARQUES et al., 2012), and it is responsible for the imbalance of the environment due to high concentrations of chemicals and pathogenic organisms dumped in the water, leading in to significant damages to human health (SCHMIDT, 2006).

The Brazilian Resolution No. 357 of the National Environmental Council (CONAMA, 2005) is responsible for classifying water resources according to water use and also delimitate and define acceptable limits of different elements in water. The water courses of Água Boa stream and lakes of the parks Arnulpho Fioravante and Antenor Martins (Dourados - MS) are classified as Class 3, where water can only be destined for: human consumption after conventional or advanced treatment; irrigation of tree, cereal and forage crops; amateur fishing; and quench thirst of animals.

Among the elements measured in CONAMA (Resolution No. 357/2005) are the physico-chemical parameters (water temperature, turbidity, $\mathrm{pH}$ and dissolved oxygen concentration) (GEMMEL; SCHMIDT, 2013), microbiological contamination detection (CETESB, 2008; Rocha et al. 2015) and the mutagenic characteristics of water. These elements are essential for monitoring water quality in watersheds (DOURADO et al., 2016; FARNLEITNER et al., 2001).

The Dourados city has a total area of $4.086,237 \mathrm{Km}^{2}$ and has a population of 212.870 inhabitants (IBGE, 2015). It is located in the southern portion of the state of Mato Grosso do Sul, at an average altitude of $430 \mathrm{~m}$, near to Serra de Maracaju (SANTANA, 2015), surrounded by several important water resources for the local economy, which are responsible for the supply of fish farms and irrigation of crops. The aim of the study was to evaluate the water quality of the Água Boa stream and the lakes of the parks Arnulpho Fioravante and Antenor Martins, belonging to Dourados city, using physico-chemical parameters, microbiological analysis and mutagenicity tests to monitoring the interference from anthropic activities and water purification capacity.

\section{Material and Methods}

\subsection{Sampling sites}

The Água Boa stream receives anthropic influence in all its extension. It is born inside the Antenor Martins Park, crosses the south of the city, receives the mouth of the Paragem stream that has its source located inside the Arnulpho Fioravante

Figure 1 - Map of the state of Mato Grosso do Sul delimiting Dourados city (A), Map of Dourados city (B) e Map delimiting the urban perimeter of Dourados $(C)$, with the water collection sites.

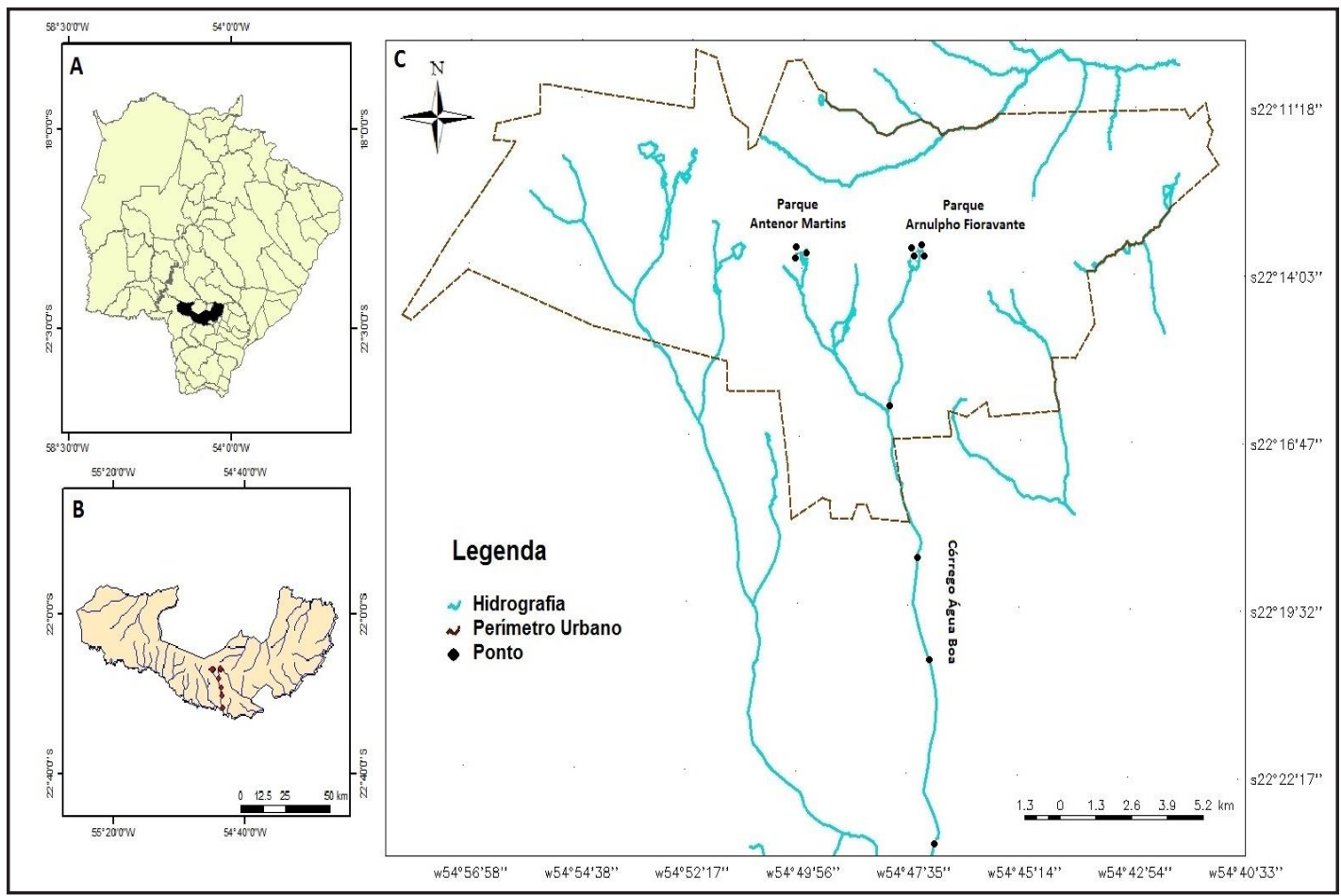


Park, and finally passes through areas of planting until it falls into the Dourados river. Water samples were collected in eleven different points, being: three in the lake of the Antenor Martins Park, four in the lake of the Arnulpho Fioravante Park and four in the Água Boa stream. (Figure 1).

\subsection{Water sampling}

The water for the microbiological analysis was collected at the watercouse margins at a depth of $20 \mathrm{~cm}$ in bottles of $500 \mathrm{~mL}$, previously sterilized. The samples were transported in a thermal box with ice, and the maximum time between the collection time of water and the beginning of the microbiological examination was 8 hours.

\subsection{Fish Collection}

Fishing nets, fishing rods, cast net fishing and sieves were used for fish collection (with prior authorization from the Environmental Police of the Environment Institute (IMAN) of the city of Dourados / MS). From each site nine specimens of Astyanax lacustris were collected and transported to the General Biology Laboratory of the Faculty of Biological and Environmental Sciences, in gallons of 20 liters with water from the places that they were collected. The anesthesia procedures of the animals and the blood collection were approved by the animal Ethics Animal Research Committee of UFGD, by Protocol no. 005/2013.

\subsection{Physico-Chemical Parameters}

The parameters temperature, $\mathrm{pH}$, dissolved oxygen, oxygen saturation, conductivity and TDS (Total Dissolved Solids) were measured using the HI 8733 portable meter for conductivity and HI 9146-10 Portable Oximeter. The results were exposed in averages of the points of each collection site and respective standard deviation.

\subsection{Coliform Analysis}

The Most Probable Number (MPN) technique was used for coliform analysis. Serial dilution of water samples and triplicate with 3 tubes of Lauryl Tryptose Broth (MERCK) were performed. Subsequently, the Brilliant Green Bile Broth (BGBB) (HIMEDIA) was used to confirm the total coliforms and the EC Broth (ISOFAR) was used for confirmation of thermotolerant coliforms. The number of total coliforms was determined by the Most Probable Number (NMP) table (SILVA et al., 2010; APHA, 2005).

\subsection{Research of Salmonella spp.}

For the research of Salmonella spp. the water sample was prepared with pre-enrichment in Buffered Peptonated Water (HIMEDIA) and selective enrichment in Selenite Cystine (SC) Broth (ISOFAR) and Rappaport Vassiliadis (RV) Enrichment Broth (ISOFAR). For the isolation of the microorganism the Xylose-Lysine-Deoxycholate (XLD) Agar (ISOFAR) (SILVA et al., 2010; APHA, 2005) was used. The colonies with transparent halo and central black spot were selected by the biochemical methods TSI (Triple Sugar Iron Agar), MIO (Motility, Indol and Ornithine) and Urea.

\subsection{Mutagenicity test}

The fishes were anesthetized with Benzocaine 1\% (soluble), then they were sacrificed and later it was collected blood from the caudal fin, which was used to perform blood smear to count the muclonucleus of red cells. From each fish was prepared one microscope slide, that was fixed in ethanol 96\% and stained with Instant-Prov (Newprov, Pinhais, Brazil), following methodology proposed by the manufacturer.

The micronucleus count was performed following the methodology proposed by Heddle (1983) and Schmid (1975). For evaluation of mutagenicity, 2000 cells of each fish were counted twice at magnification of 400X under optic microscope (Bioval). Only erythrocytes with intact cell membrane and cytoplasmic membrane were considered for analysis.

\subsection{Statistical Analysis}

The data related to the muclonucleus characteristic were submitted to preliminary exploratory analysis to eliminate discrepant data (outliers). The muclonucleus variable was submitted to Shapiro-Wilk test to verify the normality of the residues, and to Bartlett test to verify the homogeneity among the variances. After the preliminary tests, the analysis performed it was considered the generalized linear model with nested point effect in placeThe averages were compared by the Tukey test at $5 \%$ probability $(\mathrm{P}<0.5)$. Statistical analysis were performed using the R software version 2.15.0 (2012). 


\section{Results and Discussion}

\subsection{Physico-chemical Parameters}

The physico-chemical parameters (Table 1) allowed to associate the influence of anthropic contaminants (urban, effluent disposal and leaching of agrochemical products) with water quality.

Table 1 - Means and standards deviation of the physical-chemical parameters

\begin{tabular}{lcccccc}
\hline \multirow{2}{*}{ Collection Sites } & \multicolumn{5}{c}{ Parameters Analyzed } \\
\cline { 2 - 7 } & $\mathrm{T}\left({ }^{\circ} \mathrm{C}\right)$ & $\mathrm{pH}$ & $\mathrm{DO}\left(\mathrm{mg} \mathrm{L}^{-1}\right)$ & $\mathrm{SO}_{2}(\%)$ & $\left.\mathrm{EC}(\mathrm{uS} \mathrm{cm})^{-2}\right)$ & $\mathrm{TDS}\left(\mathrm{mg} \mathrm{L}^{-1}\right)$ \\
\hline Antenor Martins Park & $24,0 \pm 0,8$ & $7,4 \pm 0,4$ & $6,8 \pm 1,2$ & $82,6 \pm 15,9$ & $245,7 \pm 38,9$ & $135,3 \pm 23,1$ \\
\hline Arnulpho Fioravante Park & $24,2 \pm 1,9$ & $7,1 \pm 0,2$ & $6,4 \pm 1,8$ & $79,6 \pm 20,4$ & $353,5 \pm 36,6$ & $179,3 \pm 17,0$ \\
\hline Água Boa Stream & $21,9 \pm 3,7$ & $7,4 \pm 0,3$ & $4,1 \pm 0,8$ & $47,6 \pm 9,5$ & $233,0 \pm 24,0$ & $148,5 \pm 57,3$ \\
\hline
\end{tabular}

$\mathrm{T}$ - Temperature, $\mathrm{pH}$ - Potential of Hydrogen, DO -Dissolved Oxygen, $\mathrm{SO}_{2}-$ Oxygen Saturation, EC - Electrical Conductivity e TDS - Total dissolved solids

The measured values for water temperature and $\mathrm{pH}$ were in accordance with the allowed standards by Conama (Resolution No. 357/2005). Santos et al. (2016) reported that DO is the main parameter evaluated for water quality when it comes to studies that involve analysis of water pollution, since its application allows to evaluate the impact of pollutants on water bodies and ensure that the places that have reduced concentrations of DO $\left(<5 \mathrm{mg} \mathrm{L}^{-1}\right)$ are considered polluted. The Água Boa stream can be considered polluted, because the average value for collection site $\left(4.1 \mathrm{mg} \mathrm{L}^{-1}\right)$ and the standard deviation obtained (0.8), both the highest $\left(4.7 \mathrm{mg} \mathrm{L}^{-1}\right)$ and the lowest $\left(3.5 \mathrm{mg} \mathrm{L}^{-1}\right)$ value measured for DO were lower than the values established for non-impacted environments $\left(>5 \mathrm{mg} \mathrm{L}^{-1}\right)$.

The Arnulpho Fioravante Park presented higher mean values for both EC (353.5 uS cm$\left.{ }^{-2}\right)$ and STD (179.3 mg $\left.{ }^{\mathrm{L}-1}\right)$ and this fact can be justified by the fact that the park is located within the urban perimeter of Dourados city and receive urban effluents, by rainwater or domestic sewage. Santi et al. (2012) presented similar results to this study (EC of $\left.150-350 \mathrm{uS} \mathrm{cm}^{-2}\right)$, and reported that the electrical conductivity is directly related to the contamination that the environment receives, since areas that have strong influences of anthropic activities present high values for electrical conductivity, which characterizes the water as of low quality.

According to the Environmental Sanitation Technology Company-CETESB (2009), aquatic environments with STD levels higher than $50 \mathrm{mg} \mathrm{L}^{-1}$ already indicate water contamination by domestic sewage, soil fertilizers, agricultural inputs and industrial effluents. When the levels of SDT are higher than $100 \mathrm{mg} \mathrm{L}^{-1}$ there's an indication of impacted environments. Based on the values found for STD, it can be inferred that all collection sites studied are impacted.

\subsection{Coliform Analysis}

According to CONAMA (2000), the coliform standards allowed for water quality of water resources is 1000 coliforms/100 $\mathrm{mL}$ of sample. Comparing the results of this study with the legislation, it was possible to observe that the points P3 (1,100 $\mathrm{NMP} / 100 \mathrm{~mL})$ and $\mathrm{P} 4(1,500 \mathrm{NMP} / 100 \mathrm{~mL})$ of the lake of the Arnulpho Fioravante Park presented values above that one allowed (Table 2).

Table 2 - Results of the analysis of total coliforms expressed in the most probable number (MPN) of microorganisms per $100 \mathrm{~mL}$ of sample at different collection sites.

\begin{tabular}{lcccc}
\hline \multirow{2}{*}{ Collection Sites } & \multicolumn{4}{c}{ NMP/ $100 \mathrm{~mL}$} \\
\cline { 2 - 5 } & P1 & P2 & P3 & P4 \\
\hline Lake of Antenor Martins Park & 29 & 15 & 15 & - \\
\hline Lake of Arnulpho Fioravante Park & 460 & 93 & 1.100 & 1.500 \\
\hline Água Boa Stream & 9,2 & 75 & 150 & 93 \\
\hline
\end{tabular}

The symbol (-) represents absence of collection in this point.

In the literature, there is reports indicating the influence of urban antropic activities on the microbiological quality of watersheds in Brazil (ROCHA et al., 2015, MULLER et al., 2016). 
It was also possible to observe the interference, since the collection site that presented the highest contamination by coliforms (Lake of Arnulpho Fioravante Park) is located within the urban perimeter and receives direct interference from the discharge of urban sewage and inadequate disposal of household waste.

\subsection{Research of Salmonella spp.}

For Sant'ana et al. (2009), the risk of outbreaks of diseases transmitted by water is high, due to the possibility of bacterial contamination, especially when the water resource evaluated presents direct interference by urban population. Salmonella spp. was found in P2 and P4 of the Arnunpho Fioravante Park and in P2 and P3 of the Antenor Martins Park.

Salmonella spp. is a pathogenic microorganism of animal or human enteric origin directly related to waterborne diseases (typhoid and paratyphoid fever, bacillary dysentery, cholera and gastroenteritis). It is basically transmitted by fecal and oral pathaway, i.e. excreted in the stool of infected individuals and ingested by direct contact with contaminated food or water (BATISTA et al., 2016). The isolation of Salmonella spp. in the water of the studied parks becomes concernig because these are located within the urban perimeter of Dourados and the population regularly visit them, which allows the direct contact with the water in a way that facilitates the contamination of the population. Absence of Salmonella spp. in the Água Boa stream may be related to the phenomenon of water purification.

\subsection{Mutagenicity test}

The presence of contaminants (organic or inorganic) in the water from urban effluents evaluated on the studied sites may be related to the genetic alteration found in the specimens of Astyanax lacustris.

Considering the points and collection sites analized, the Água Boa stream was significant $(\mathrm{P}<0.001)$ in relations to the MNC means when compared to the other sites, in the analysis analysis of Degree of Freedom (DOF). The micronucleus mean and standard deviation for Antenor Martins Lake (1.96 \pm 0.10$)$, Arnulpho Fioravante Lake (4.31 \pm 0.13$)$ and Água Boa stream $(6.2 \pm 0.17)$ were shown in Figure 2 .

Figure 2 - Means for micronucleus number to the collection sites

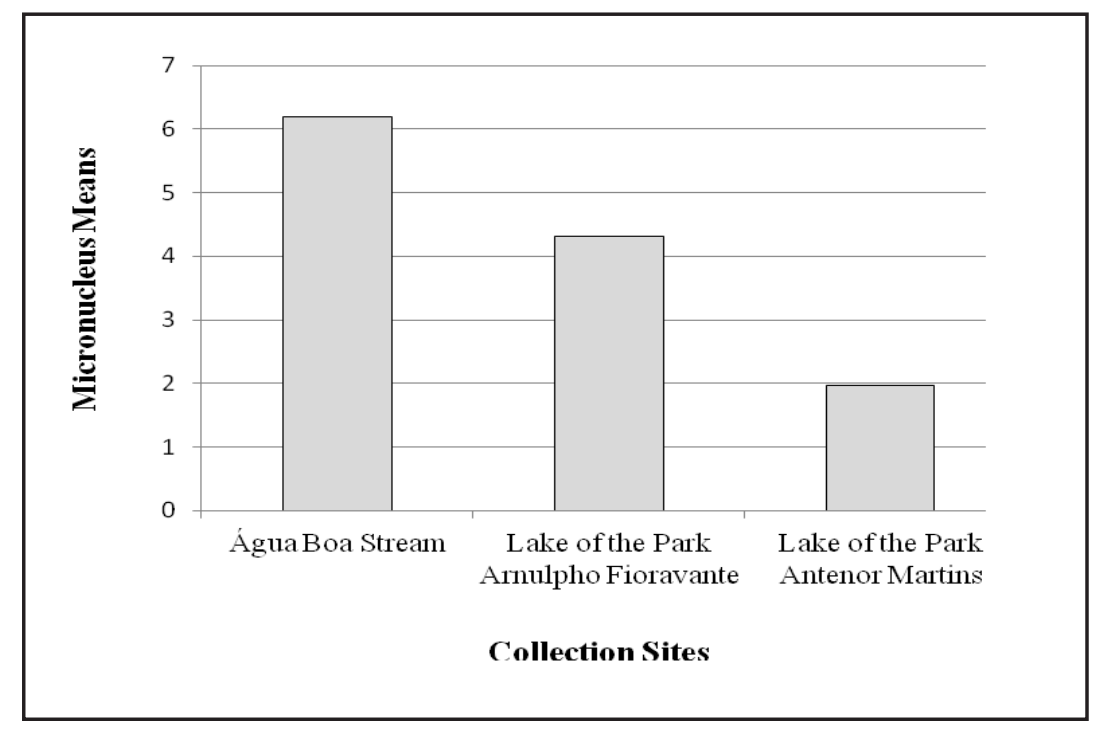

Comparing the difference among the muclonucleus means from all collection sites by the Tukey test at the 5\% probability level $(\mathrm{P}<0.5)$, the Água Boa stream presented muclonucleus indexes that significantly differed from all others collection sites (Figure 2). The lake of the Arnulpho Fioravante Park presented significant higher indices for the amount of micronucleus when compared to the lake of the Antenor Martins Park.

In the literature there are researches reporting that the cellular damages may be directly related to other factors, such as contamination of the environment by pesticides, air pollutants and organic and inorganic materials, mainly from rainwater runoff (BOLLMANN, MARQUES, 2006; MACEDA et al., 2015). The highest micronucleus mean in the Água Boa stream can be explained by the transport of the pollutants contained in the water from the lakes of the parks to the stream. In addition, there is direct interference of household sewage that passes through the southern outskirts of the Dourados city and also leached agrochemicals of the extensive areas of crops (sugarcane, soybean and corn) near to the stream (ROCHA et al, 2015). 


\section{Conclusion}

The physical-chemical evaluation identified contamination in all collection sites. Regarding the microbiological parameters, greater contamination was observed in the Arnulpho Fioravante and Antenor Martins Parks. Although Salmonella spp. was identified in both parks, its absence in the Água Boa stream can be explained by the water purification capacity. The stream Água Boa receives water from the parks which may imply an increase in contamination. As a consequence of this fact it was identified higher number of alterations in the erythrocytes of the fish, when compared to the results of the parks. Measures for the conservation and preservation of the aquatic ecosystem, improvements in the supervision of current municipal legislation, and educational environmental actions for the local population are necessary for the preservation of these environments.

\section{Acknowledgements}

To the Federal University of Grande Dourados (UFGD) for the logistic support and the Foundation for Support to the Development of Education, Science and Technology of the State of Mato Grosso do Sul (FUNDECT) and the Coordination for the Improvement of Higher Education Personnel (CAPES) for the support financial.

\section{References}

ANIDO NMR. Caracterização hidrológica de uma microbacia experimental visando identificar indicadores de monitoramento ambiental [dissertation]. Piracicaba: Escola Superior de Agricultura “Luis de Queiroz”, Universidade de São Paulo/ESALQ/ USP; 2002. 69 p.

APHAAWWA, WEF. Standard Methods for the Examination of Water and Wastewater. 21st ed. Washington: D.C; 2005.1368 p.

BATISTA GVF, SILVA GCS, PESSOA GT, RODRIGUES RPR, BARBOSA MAPS, SANCHES MP et al. Análise microbiológica da água do rio Poti no perímetro urbano do município de Teresina, Piauí. PUBVET. 2016;10(6):470-476.

BOLLMANN HA, MARQUES DMLM. Influência da densidade populacional nas relações entre matéria orgânica carbonácea, nitrogênio e fósforo em rios urbanos situados em áreas com baixa cobertura sanitária. Eng. Sanit. Ambient. 2006;1:343-352.

CARVALHO AR, SCHLITTLE FHM, TORNISIELO VL. Relações da atividade agropecuária com parâmetros físicos químicos da água. Quím. Nova. 2000;23:618-622.

CETESB - Companhia de Tecnologia de Saneamento Ambiental. Qualidade das Águas Interiores no Estado de São Paulo: Significado Ambiental e Sanitário das Variáveis de Qualidade das Águas e dos Sedimentos e Metodologias Analíticas e de Amostragem. DC: CETESB, 2009. 44 p.

CETESB - Companhia de Tecnologia de Saneamento Ambiental. Relatório de qualidade das águas interiores do estado de São Paulo 2007. São Paulo: Secretaria do Meio Ambiente, DC: CETESB, 2008. 521 p.

CONAMA - Ministério do Meio Ambiente, Conselho Nacional do Meio Ambiente. Resolução n 274 . Define os critérios de balneabilidade em águas brasileiras. Diário Oficial da União (Brasília). 2000 jan 25.

CONAMA - Ministério do Meio Ambiente, Conselho Nacional do Meio Ambiente. Resolução n 357 . Dispõe sobre a classificação dos corpos de água e diretrizes ambientais para o seu enquadramento, bem como estabelece as condições e padrões de lançamento de efluentes, e dá outras providências. Diário Oficial da União (Brasília). 2005 mar 18.

FARNLEITNER AH, KIRSCHNER AKT, ZECHMEISTER G, KAVKA TC, MACH RL. [Untersuchungstechniken in der mikrobiologischen Analyse von Wasser und Gewässern: Staus Quo und Perspektiven. ÖWAV Schriftenreihe] Austrian Association of Water and Waste Management. 2001; 150:125-154. Russo.

HEDDLE JA, HITE M, KIRKHART B, MAVOURNIN K, MCGREGOR JT, NEWELL GW et al. The induction of muclonucleus as a mensure genotoxicity. Mutat. Res. 1983;123:61-118. 
IBGE - Instituto Brasileiro de Geografia e Estatística [Internet]. Brasília: Ministério do Planejamento, Orçamento e Gestão (BR) [cited 2016 mar 27]. Cidades 2013. Available from: http://www.cidades.ibge.gov.br/xtras/perfil.php?lang=\&codmun $=500370 \&$ searchmato-grosso-do-sul dourados.

LIVINGSTONE DR. The fate of organic xenobiotics in aquatic ecosystems: quantitative and qualitative differences in biotransformation by invertebrates and fish. Comp. Biochem. Physio. 1998;120:43-49.

MACEDA EB, GRISOLIA AB, VAINI JO, CANDIDO LS. Uso de biomarcadores para monitoramento das águas do Córrego Arara no município de Rio Brilhante, MS, Brasil. Rev. Ambient. Água. 2016;10(1):75.

MARQUES, R. F. P. V.; SILVA, A. M.; RODRIGUES, L. S.; COELHO, G. Impacts of urban solid waste disposal on the quality of surface water in three cities of Minas Gerais - Brazil. Ciência e Agrotecnologia. 2012;36:684-692.

MULLER T, GRANADA CEG, SPEROTTO RA. Qualidade da água de três locais com potenciais fontes de contaminação no Rio Taquari, RS. Rev. Ambient. Água. 2016;11(1):75.

ROCHA MP, DOURADO PLR, RODRIGUES MS, RAPOSO JR JL, GRISOLIA AB, OLIVEIRA KMP. The influence of industrial and agricultural waste on water quality in the Água Boa stream (Dourados, Mato Grosso do Sul, Brazil). Environ. Monit. Assess. 2015;187:117-129.

SANT'ANA GRS, SANT’ANA CER, MACIEL JR, COSTA CR. Análise físico-química e microbiológica da água do córrego de Cascavel. Revista Proc. Químicos. 2009;3:37- 47.

SANTANA JP, DE CARVALHO EM. Efeito da urbanização sobre a fauna de insetos aquáticos de um riacho de Dourados, Mato Grosso do Sul. In: Anais do Encontro de Iniciação Científica [CD-ROM]; 2015 jul 12-14; Dourados, Brasil. p. 1-5.

SANTI GM, FURTADO CM, MENEZES RS, KEPPELER EC. Variabilidade Espacial De Parâmetros e Indicadores de Qualidade da Água na Sub-Bacia Hidrográfica do Igarapé São Francisco, Rio Branco, Acre, Brasil. Ecologia Aplicada, 2012;11(1):23-31.

SANTOS JM, SANTIAGO BEC, LIMA KC, GONÇALVES MJS. Poluição Hídrica em Rios Tropicais: Aplicação do Azul de Metileno (AM) no Estudo do Rio Itapicuru - Perímetro Urbano do Município de Queimadas (Bahia/Brasil). GEOgraphia. 2016;18(36):149 - 169 .

SCHMID W. The micronucleus test. Mutat. Res.1975;31(1):9-15.

SILVA N, JUNQUEIRA VCA, SILVEIRA NFA, TANIWAKI MH, SANTOS RFS, GOMES RAR. Manual de métodos de análises microbiológicas de alimentos e água. São Paulo: Varela; 2010.

Monyque Palagano da Rocha
Faculdade de Ciências Exatas e Tecnologia, Universidade Federal da Grande
Dourados, Mato Grosso do Sul, Brasil
E-mail:monyque_da_rocha@hotmail.com
Participação do autor:

Jussara Oliveira Vaini
Universidade de Mogi das Cruzes, São Paulo, Brasil
E-mail: jussaravaini@hotmail.com
Participação do autor:

\section{Bruno do Amaral Crispim}

Faculdade de Ciências Exatas e Tecnologia, Universidade Federal da Grande

Dourados, Mato Grosso do Sul, Brasil

E-mail: brunocrispim.bio@gmail.com

Participação do autor: 


\section{Leonardo de Oliveira Seno ${ }^{3}$}

${ }^{3}$ Faculdade de Ciências Agrárias, Universidade Federal da Grande Dourados, Mato Grosso do Sul, Brasil

E-mail:leonardoseno@ufgd.edu.br

\section{Participação do autor:}

\section{Kelly Mari Pires de Oliveira}

Faculdade de Ciências Biológicas e Ambientais, Universidade Federal da Grande Dourados, Mato Grosso do Sul , Brasil

E-mail: kellyoliveira@ufgd.edu.br

Participação do autor:

\section{Alexéia Barufatti Grisolia}

Faculdade de Ciências Biológicas e Ambientais, Universidade Federal da Grande

Dourados, Mato Grosso do Sul, Brasil

E-mail: alexeiagrisolia@ufgd.edu.br

Participação do autor: 